\title{
MERAIH PELUANG DENGAN KOMUNIKASI DIGITAL DALAM MENGHADAPI MEA
}

\author{
Carly Scheffer \\ Fakultas Ilmu Sosial dan Ilmu Politik \\ Universitas Pelita Harapan, Karawaci - Tangerang \\ carly.scheffer@uph.edu
}

\begin{abstract}
Abstrak
Salah-satu faktor pendorong globalisasi ialah teknologi digital. Komunikasi digital menjadi suatu kebutuhan bagi masyarakat Indonesia tak terkecuali komunitas gereja. Teknologi digital merupakan pengembangan dari teknologi sebelumnya, yaitu analog. Baik analog maupun digital merupakan proses transmisi frekuensi dimana digital memiliki kelebihan-kelebihan dibanding teknologi analog. Itu sebabnya teknologi digital menjadi keniscayaan bagi setiap individu. Kegiatan PkM ini berbentuk seminar interdisipliner yang diawali oleh pembicara pertama menjelaskan hubungan antara negara-negara dan lebih spesifik tentang Masyarakat Ekonomi ASEAN sebagai respon atas globalisasi. Pembicara kedua melanjutkan dengan topik hubungan antara negara dengan warga negaranya, seperti diatur dalam undang-undang ketenagakerjaan di Indonesia. Dan akhirnya, pembicara ketiga mengerucut pada peran individu dalam meningkatkan keterampilannya, terutama untuk menjawab tantangan MEA melalui kemampuan komunikasi digital dan komunikasi bisnis. Komunikasi digital dalam PkM ini menekankan pada penggunaan perangkat-perangkat digital maupun piranti lunak ataupun aplikasi-aplikasi komputer yang membantu individu dalam meraih peluang kerja di era digital saat ini. Dosen dan mahasiswa ilmu komunikasi berbagi seputar keterampilan berkomunikasi menggunakan Canva, Skype dan LinkedIn serta tips menghadapi wawancara kerja dan pembuatan video resume. Target peserta seminar ialah usia produktif dan seminar ini merupakan program kemitraan bersama Persekutuan Gereja-Gereja Indonesia di wilayah Banten dengan mengambil lokasi seminar di GPIB Jemaat Karunia, Ciputat, Tangerang Selatan.
\end{abstract}

Kata kunci: ASEAN, Digital, Komunikasi Bisnis, PGIW 


\section{LATAR-BELAKANG: MEA}

Indonesia secara proaktif memberlakukan Masyarakat Ekonomi ASEAN atau kerap disebut MEA itu pada 1 Januari 2016. Sebagai salah-satu negara penggagas ASEAN, Indonesia bersama dengan sejumlah negara di kawasan Asia Tenggara (ASEAN) berperan aktif dalam menyikapi perubahan ekonomi global itu. ASEAN menjadi usaha kolektif bagi negara-negara kawasan Asia Tenggara dalam menyikapi perubahan ekonomi global yang tidak menentu sifatnya. Strategi ASEAN dalam menyikapi perubahan ekonomi itu ditempuh dengan mendorong integrasi ekonomi di antara negara anggotanya. Gagasan untuk mendorong integrasi ekonomi itu sesungguhnya merupakan ide yang relatif baru. Walaupun ASEAN merupakan forum kerjasama ekonomi regional yang dibentuk pada 1967, namun kalangan pemimpin ASEAN awalnya tidak berkeinginan untuk mendorong integrasi ekonomi di antara negara anggotanya. Gagasan untuk mendorong integrasi ekonomi kawasan diawali sejak berakhirnya Perang Dingin, yaitu awal 1990an. Gagasan untuk mendorong integrasi ekonomi kawasan itu dirintis dengan pembentukan AFTA (ASEAN Free Trade Area) pada 1992, dan hendak diperdalam dengan dicanangkannya pembentukan Masyarakat Ekonomi ASEAN (MEA). MEA akan menginternalisasi proses integrasi ekonomi di kawasan Asia Tenggara, yaitu membuka peluang peningkatan arus barang, jasa, investasi bahkan akan membuka mobilitas tenaga-kerja di kawasan ASEAN. Proses integrasi kawasan ini akan membuka peluang dan tantangan bagi Indonesia. Meningkatnya arus investasi ke Indonesia akan memperluas peluang bagi tenaga kerja Indonesia. (CERMATI, 2019)
Pasar bebas ASEAN ini tentunya bisa memiliki 2 sisi dampak, baik yang positif maupun negatif. Dampak bersifat positif disebut juga sebagai peluang, Sedangkan dampak yang cenderung negatif menjadi tantangan. Makalah ini hendak menyoroti kedua dampak MEA- peluang dan tantangan dan bagaimana disiplin ilmu komunikasi menyikapi fenomena MEA ini.

Dari sudut pandang positif, maka masyarakat Indonesia dituntut untuk meningkatkan kualitas dirinya sendiri maupun kualitas produk dan jasa yang dihasilkannya. Lebih dari 3 tahun sejak diberlakukannya MEA, yaitu tahun 2016, namun data yang diperoleh dari BPS (Biro Pusat Statistik) menunjukkan bahwa angkatan kerja Indonesia pada 2017 mencapai 131 juta orang, dan dari jumlah itu sebesar 60 persen umumnya masih berpendidikan SMP, SD dan tidak tamat SD (Detik, 2018). Keterbatasan kualitas sumberdaya manusia itu merupakan tantangan yang serius dalam memasuki pelaksanaan MEA. Sehubungan dengan itu pendidikan ketrampilan bagi angkatan kerja Indonesia menjadi kebutuhan yang sangat penting bagi tenaga kerja Indonesia. Sementara data berdasarkan UNDP (badan PBB yang berfokus pada dimensi pembangunan negara-negara di dunia), menyatakan human development index negara Indonesia ialah 0.694 atau ada pada peringkat 116 dari 192 negara-negara di seluruh dunia (UNDP, 2019). Keberlanjutan bidang sosial-ekonomi ditunjukkan dengan index angkatan kerja terampil di Indonesia, yaitu hanya $40.8 \%$. Berdasarkan data BPS tahun 2017 dan data UNDP tahun 2018, dapat disimpulkan masih banyak masyarakat Indonesia yang belum memiliki pendidikan cukup (bahkan tidak lulus SMA atau wajib belajar 12 tahun) serta dari angkatan kerja Nama Sub tema Penelitian 
Indonesia juga masih banyak yang belum memiliki keterampilan yang mumpuni untuk memasuki dunia kerja. Hal inilah yang disebut sebagai tantangan memasuki MEA dimana sebagian besar masyarakat Indonesia belum terdidik ataupun terampil. Kenyataan ini akan berkembang menjadi dampak negatif, jika pemerintah dan masyarakat Indonesia hanya berdiam diri atau menjadi penonton dari perubahan ekonomi global saat ini. Ada sedikitnya 12 sektor prioritas MEA dan 8 profesi yang dibuka kesempatan oleh pemerintah Indonesia. Ke-12 sektor prioritas itu adalah pariwisata, kesehatan, logistik, penerbangan, komunikasi, dan informatika, pertanian, kayu, karet, otomotif, tekstil atau garmen, elektronik dan perikanan. Hingga Agustus 2015, telah ditetapkan total 482 Standar Kompetensi Kerja Nasional Indonesia (SKKNI) untuk semua sektor. Delapan profesi yang terkena kebijakan pasar bebas tersebut telah tertuang dalam ASEAN Mutual Recognition Arrangement (MRA). MRA masing-masing profesi telah menetapkan standar dan kompetensi yang diperlukan di kancah ASEAN. Nantinya, Indonesia bisa menerima tenaga kerja dari ASEAN untuk profesi-profesi di atas, begitu juga sebaliknya. Ke-8 profesi itu ialah insinyur, arsitek, perawat, tenaga survei, tenaga pariwisata, praktisi medis, dokter gigi, dan akuntan. MEA 2016 direncanakan hanya membuka delapan profesi di atas secara bebas (Career News, 2019). Jadi, baik sudut pandang positif maupun negatif, terbukti dari respon pemerintah maupun masyarakat Indonesia sendiri dalam hal menyikapi permasalahan tenaga kerja terdidik dan terampil juga bagaimana menyikapi ke-12 sektor dan ke-8 profesi yang memiliki posisi tawar tinggi di seputar wilayah ASEAN.

\section{MITRA: PGIW BANTEN}

Peningkatan kualitas angkatan kerja Indonesia memerlukan partisipasi yang luas, baik dari pemerintah maupun berbagai elemen masyarakat, seperti: NGOs atau LSM serta komunitas-komunitas agama. Adapun mitra yang dipilih oleh TIM PkM berasal dari suatu komunitas agama, yaitu Persekutuan Gereja-Gereja di Indonesia wilayah Banten (PGIW Banten). Mitra dipilih karena diaggap merepresentasikan suatu komunitas tertentu dan terdiri dari masyarakat dari segala jenis usia. Globalisasi ekonomi memberikan berbagai dampak positif dan negatif yang juga memberikan pengarauh terhadap komunitas PGIW Banten. Globalisasi membuka lebih banyak kesempatan kerja bagi masyarakat Indonesia, namun juga memberikan tuntutan yang lebih tinggi terhadap kualitas yang diharapkan oleh para pemberi kerja. Lebih dari itu, kehadiran MEA akan membuka kesempatan yang lebih mudah untuk mempekerjakaan tenaga kerja asing- seperti pemaparan di bagian latar-belakang ada 12 sektor dan 8 profesi-dari negara ASEAN lainnya.

Sehingga, dari sekian banyak permasalahan yang dihadapi oleh mitra di era globalisasi, kami memilih untuk menyoroti tantangan-tantangan mitra dalam masalah ketenagakerjaan dengan harapan untuk membuka peluang-peluang yang baru bagi mereka. Sesuai data, $45 \%$ dari keseluruhan komunitas PGIW Banten berada diusia produktif kerja (usia 18-50 tahun). Namun, sebagian besar dari presentase tersebut masih belum memiliki pekerjaan ataupun merasa kurang puas dengan pekerjaan yang mereka geluti. Dengan situasi tersebut, maka kami berharap untuk memberikan kontribusi terhadap tantangan di bidang ketenagakerjaan yang mitra sedang hadapi.

Kemajuan teknologi dalam komunikasi dan transportasi telah mendorong proses globalisasi ekonomi. Globalisasi ekonomi telah meningkatkan ketergantungan (interdepency) dan keterkaitan (inter-conectedness) antar negara. Indonesia bersama-sama dengan negara-negara ASEAN mencanangkan pembentukan MEA dalam menyikapi perubahan ekonomi global. MEA 
merupakan project of regionalisme dan menjadi strategi kolektif bagi negara-negara yang tergabung dalam ASEAN dalam menghadapi tantangan perubahan ekonomi global itu. Bagi Indonesia, keterbatasan kualitas tenaga kerja merupakan tantangan yang serius dalam memanfaatkan peluang perubahan ekonomi regional dan global. Rancangan PkM (Pengabdian kepada Masyarakat) ini dimaksudkan untuk memberikan bekal pengetahuan dan ketrampilan bagi tenaga kerja Indonesia. Dalam hal ini adalah mitra PGIW Banten, demi menyongsong perubahan ekonomi nasional, regional dan global. Sehubungan dengan itu, masalah pokok yang diajukan adalah jenis pengetahuan dan ketrampilan apakah yang relevan diperlukan dalam membekali tenaga kerja Indonesia, serta bagaimana kita dapat memaksimalkan penggunaan media untuk dalam menghadapi arus globalisasi.

Pembentukan PGIW Banten bermula dari pertemuan persiapan di GKI Serang pada tanggal 19 Maret 2001. Pertemuan ini dihadiri oleh utusan jemaat GPIB, HKBP, GKJ, GKP, GKPI, GBI, dan GKI disertai Ketua Umum Persekutuan Gerejagereja di Indonesia (Persekutuan Gereja-Gereja di Indonesia, 2019). Dari pertemuan ini dibentuklah tim kerja yang bertanggung jawab menyusun struktur dan personalianya.

\section{Tim kerja}

Tim kerja terdiri dari 7 orang, yaitu:

- Pnt. Drs. A. Saragih (GPIB),

- Pdt. S. Situngkir (HKBP),

- Pdt. G. Tobing (GKPI),

- Pdt. Pramudianto (GKJ),

- Pdt. D. H. Pandiangan (GBI),

- Pnt. Kusnandar Sulaeman (GKP), dan

- Pdt. Herman Baeha (GKI).

\section{Pertemuan pendirian}

Pertemuan berikutnya diadakan pada tanggal 19 Mei 2001 di GKJ Tangerang. Utusan jemaat yang hadir berasal dari GKI, GKJ, GKP, HKBP, GPIB, BNKP, GKPI, GKMI, GMI dan PGIS Tangerang. Pada akhir pertemuan tersebut, diputuskan untuk membentuk PGI Wilayah Banten dan resmi didirikan pada tanggal 28 Mei 2001. Pembentukan PGIW Banten ini sendiri berkaitan erat dengan terbentuknya Banten dari kabupaten yang masuk ke dalam provinsi Jawa Barat menjadi sebuah provinsi mandiri.

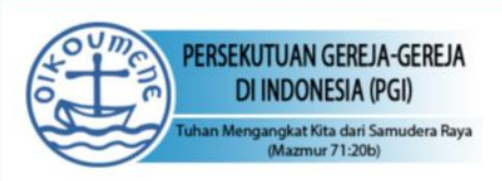

Gambar 1 - Logo PGI

Demikianlah, seminar interdispliner ini dilaksanakan pada hari Sabtu, 29 Juni 2019 mulai pk.08.00 WIB dengan target peserta pada usia produktif serta mengambil tempat pada GPIB Jemaat Karunia, Ciputat, yang merupakan komunitas Kristen.

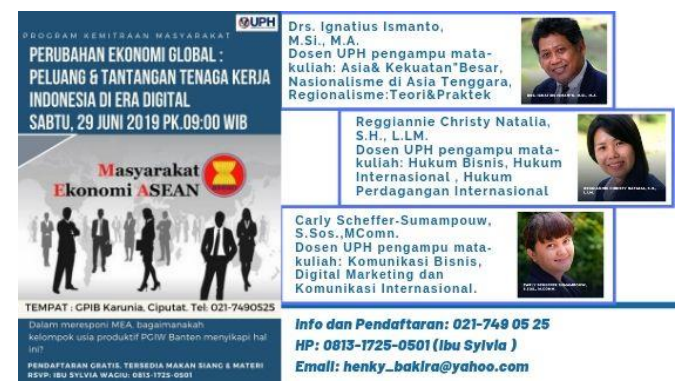

Gambar 2 - Disain spanduk untuk promosi dan saat acara hari $\mathrm{H}$.

\section{METODE}

\section{Makna Bekerja}


Penulis sebagai pembicara ketiga, membuka pelatihan ini dengan wawasan tentang "makna bekerja bagi orang Kristen". Selain alasan bahwa komunitas yang dilayani ialah komunitas kristiani, jauh daripada itu, penulis meyakini bahwa sebagai ciptaan Tuhan yang paling mulia, manusia diciptakan Yang Maha Kuasa dengan suatu tujuan tertentu. Dan tujuan mulia tersebut pasti dimulai dengan bekerja. Agama apapun pasti menghendaki agar setiap umatnya dapat bekerja, bukan sekedar memenuhi kebutuhan hidupnya, melainkan untuk hidup itu sendiri. Menurut Alkitab, seperti dikutip pada Keller, 2012, manusia tidak hanya butuh uang dari hasil pekerjaannya untuk bertahan hidup; melainkan manusia membutuhkan pekerjaan itu sendiri untuk bertahan hidup yang berarti bekerja memungkinkan kita kita hidup sepenuhnya sebagai manusia. Ungkapan yang diberikan oleh Timothy Keller: WORK IS FOOD FOR OUR SOUL (pekerjaan ialah makanan bagi jiwa kita) mengawali presentasi "Meraih Peluang dengan Komunikasi Digital dalam Menghadapi MEA".

Alkitab dimulai dengan pembicaraan mengenai kerja (proses penciptaan). Penulis kitab Kejadian menggambarkan segala ciptaan Allah di dunia ini sebagai suatu pekerjaan. Jadi, pada mulanya, Allah bekerja dan Dia bekerja dengan penuh sukacita. Pasal 2 kitab Kejadian berlanjut dengan menunjukkan pekerjaan Allah tidak hanya untuk menciptakan melainkan juga untuk merawat ciptaanNYA (para teolog menyebut ini sebagai: providensia). Alkitab menyatakan bahwa Allah kerap melanjutkan peran ini yaitu sebagai Penyedia/Provider. (Mazmur 104:10-22; Mazmur 145: 14-16).

Prinsip Alkitabiah lainnya mengenai makna bekerja dapat dilihat bahwa Allah tidak hanya bekerja melainkan juga menugaskan para pekerja untuk melanjutkan pekerjaanNYA. Allah bekerja melalui kita-umatNYA. Yesus berkata dalam Yohanes 5:17 - Bapa-Ku bekerja sampai sekarang, maka Aku pun bekerja juga. Allah Bapa sebagai Pencipta telah memberikan teladan dengan bekerja melalui proses penciptaan, Allah Anak yaitu Tuhan Yesus juga meneladani BapaNya. Giliran manusia juga meneladani PenciptaNya untuk dapat meneruskan pekerjaan Allah Bapa dan Allah Anak di muka bumi ini. Prinsip ini penting untuk dipahami bahwa jika manusia bekerja, ia harus ingat bahwa pekerjaan yang ia lakukan adalah berkat Allah dan bertujuan melanjutkan atau menjadi perpanjangan tangan Allah di muka bumi ini.

Sementara durasi yang tertulis dalam Alkitab mengenai berapa lama manusia harus bekerja tercatat pada Keluaran 20:9: enam hari lamanya engkau akan bekerja dan melakukan segala pekerjaanmu serta Kejadian 2:1-3: Allah berhenti bekerja/beristirahat pada hari ketujuh. Ketika kita berpikir, "Saya benci bekerja!" maka perlu diingat bahwa terlepas dari kenyataan dimana pekerjaan terkadang mengingatkan kita akan kutuk dari segala dosa kita, kerja itu sendiri bukanlah kutuk. Bahkan kita diciptakan untuk bekerja (Kejadian 2:15). Akan tetapi jika kita merenung dan ternyata pekerjaan telah menghabiskan waktu\& energi kita, ingatlah bahwa kita juga harus menghormati hakikat keterbatasan dari bekerja. Tidak ada titik awal yang lebih baik daripada memahami pekerjaan menjadi bermakna jikalau kita dapat benar-benar paham tentang teologi keseimbangan antara bekerja dan beristirahat. Josef Piper- filosofer katolik jerman abad $20^{\text {th }}$ - jika kita tidak berhenti bekerja dan mengambil waktu untuk memuji Tuhan, sederhananya berkontemplasi dan menikmati dunia ini - termasuk menikmati hasil buah pekerjaan kita- kita tidak dapat benar-benar merasakan bahwa hidup ini berarti (Keller, 2012).

Pada akhirnya, manusia harus bekerja bukan saja untuk menghidupi dirinya sendiri beserta keluarga melainkan karena manusia diciptakan oleh Sang Pencipta untuk bekerja. Manusia adalah ciptaan Tuhan yang mulia, ia memiliki segala potensi yang tidak dimiliki oleh ciptaan lainnya (binatang dan tumbuhan), namun durasi seseorang dapat bekerja hanyalah 6 hari dalam seminggu dimana hari ke-7, ia harus berisitirahat, itulah hakikat bekerja. (Alsdorf, 2012)

(Lembaga Alkitab Indonesia , 1974)

\section{Komunikasi Digital}

$$
\text { Nama Sub tema Penelitian }
$$


Komunikasi digital ialah suatu proses komunikasi dengan menggunakan perangkatperangkat digital. Pengertian digital ialah suatu teknologi elektronik yang membangkitkan, menyimpan serta memroses dan mentransmisi data dalam bentuk rentetan angka 0 dan 1, angka-angka ini disebut juga bit atau dalam komputer disebut sebagai "byte". Teknologi digital merupakan pembaharuan dari teknologi analog, dimana pengertian analog ialah transmisi elektronik yang dicapai melalui menambahkan signal dari frekuensi amplitude kepada gelombang frekuensi elektromagnetik. Secara konvensional, transmisi telepon dan penyiaran menggunakan teknologi analog (Turow. 2014:12). Jika teknologi digital merupakan pembaharuan dari teknologi analog, maka niscaya perangkat-perangkat komunikasi pun akan beralih menjadi digital. Adapun perangkat komunikasi digital dewasa ini antara lain: telepon genggam, tablet, kamera, laptop bahkan pesawat radio dan televisi pun sudah beranjak menjadi digital.

\section{Komunikasi Bisnis}

Pengertian komunikasi bisnis ialah keterampilan berkomunikasi yang kerap dibutuhkan dalam dunia bisnis. Keterampilan tersebut dimulai dari upaya individu mendapatkan pekerjaan. Oleh sebab itu, keterampilan pertama yang diperlukan seorang tenaga kerja ialah keterampilan menulis. Keterampilan menulis seorang tenaga kerja dimulai saat ia melamar pekerjaan. Adapun materi-materi komunikasi yang harus ia buat ialah surat lamaran pekerjaan serta daftar riwayat hidup. Dengan berkembangnya teknologi komunikasi dewasa ini, sudah semakin banyak aplikasi-aplikasi perangkat lunak komputer yang memfasilitasi pekerja untuk menciptakan baik surat lamaran maupun daftar riwayat hidup yang memiliki tampilan disain yang menarik serta professional. Berbagai kebutuhan komunikasi termasuk kartu nama dan daftar riwayat hidup dapat dibuat melalui suatu aplikasi komputer bernama CANVA. Selanjutnya, pada bab hasil dan pembahasan, penulis akan membahas penerapan atas konsep komunikasi digital dan komunikasi bisnis dalam menyikapi tantangan MEA bagi tenaga kerja Indonesia. Sementara keterampilan lain yang dibutuhkan dalam dunia bisnis ialah keterampilan berbicara. Dalam konteks ketenagakerjaan, penulis menghasilkan modul tentang teknik unggul dalam wawancara kerja (Kaczmarek, 2013).

\section{Seminar Interdisipliner}

Metode yang digunakan untuk menyelesaikan permasalahan mitra terkait kesiapan komunitas menghadapi MEA, Tim PkM merumuskan suatu seminar sehari yang sifatnya interdisipliner. Seminar tersebut diadakan pada hari Sabtu, 29 Juni 2019 dan mengambil lokasi GPIB Jemaat Karunia, Ciputat, yang juga merupakan gereja anggota dari PGIW Banten. Dimana ada sedikitnya 3 disiplin ilmu atau 3 dosen dari disiplin ilmu yang berbeda. Pembicara pertama berbicara tentang sejarah globalisasi, ciri dan karakteristiknya hingga mengerucut kepada respon negara-negara ASEAN sehingga terbentuklah MEA. Pemaparan materi dalam bentuk powerpoint sekitar 60 menit, kemudian dilanjutkan dengan tanya-jawab sekitar 30 menit untuk membahas topik "Integrasi Ekonomi ASEAN". Pembicara kedua berasal dari disiplin ilmu hukum dan materi yang dibawakannya ialah tentang hak dan kewajiban setiap warga negara dalam hal bekerja sesuai dengan Undang-Undang No.13 tahun 2003 tentang ketenagakerjaan. Jika pembicara pertama membicarakan tentang hubungan antara negara-negara di wilayah ASEAN, maka pembicara kedua mengajarkan tentang bagaimana negara mengatur warga negara nya dalam hal ketenagakerjaan. Akhirnya, seminar ini ditutup dengan penulis sebagai pembicara ketiga yang menitikberatkan pada peningkatan keterampilan individu dalam upaya meningkatkan daya saing di dunia kerja. Kata kunci yang menghubungkan ketiga pembicara ini ialah tenaga kerja. Pembicara ketiga memaparkan, tehnik komunikasi apa saja yang diperlukan terutama untuk unggul pada era digital ini. Dunia digital menciptakan peluang-peluang bagi tenaga kerja Nama Sub tema Penelitian 
Indonesia untuk meraih kesempatan mendapatkan pekerjaan idaman. Cara meraih kesempatan mendapatkan pekerjaan idaman itu dengan memanfaatkan aplikasi-aplikasi komputer yang tercipta dewasa ini maupun tehnik berkomunikasi yang meliputi keterampilan menulis (membuat surat lamaran kerja dan CV) serta keterampilan berbicara (unggul dalam wawancara pekerjaan serta membuat video resume). Keterampilan berkomunikasi serta perangkat digital yang diperkenalkan pada seminar ini terbatas pada level kognitif. Keterbatasan waktu tidak memungkinkan peserta untuk mendapatkan kesempatan praktek berkomunikasi pada era digital. Secara detil, penjabaran komunikasi digital dan komunikasi bisnis akan diuraikan pada bab hasil dan pembahasan di bawah ini.

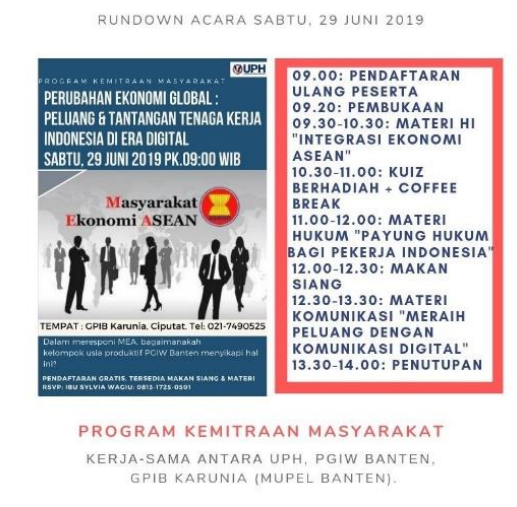

Gambar 3 - Rundown acara seminar interdisipliner

\section{HASIL \& PEMBAHASAN}

\section{Komunikasi Digital: Canva, Skype, LinkedIN}

Sesuai dengan rundown acara seminar pada gambar 3 diatas, penulis sebagai pembicara ketiga memaparkan sedikitnya 3 aplikasi perangkat lunak komputer yang bermanfaat untuk upaya pencarian kerja. Canva merupakan aplikasi komputer yang memungkinkan individu tanpa keahlian disain dapat menciptakan suatu daftar riwayat hidup atau sering disebut dengan CV. Aplikasi ini memampukan individu menciptakan produk apapun yang indah untuk dilihat atau dibaca. CV hanyalah salah-satu produk komunikasi yang bisa dibuat dengan canva.
Gambar 2 dan gambar 3 pada halaman diatas pun dibuat dengan canva. Selain gratis, aplikasi canva dapat diakses melalui computer, laptop bahkan telepon genggam selama kita memiliki paket data internet.

Aplikasi kedua yang dianjurkan penulis dalam hal ketenagakerjaan ialah SKYPE. Aplikasi ini memampukan seorang pelamar dapat melamar pekerjaan tidak hanya lintas pulau melainkan juga lintas negara. Dalam konteks ASEAN, tentu aplikasi ini sangat bermanfaat. Seorang individu yang hendak melamar pekerjaan di luar wilayah Indonesia, tidak perlu menghabiskan biaya untuk transportasi perjalanan untuk melakukan proses wawancara. Sebelum individu tersebut dinyatakan berhasil mendapatkan pekerjaan tentu proses terkait seleksi awal dapat dilakukan via e-mail ataupun wawancara jarak jauh menggunakan skype. Skype adalah aplikasi komputer yang memungkinkan beberapa individu untuk dapat berbicara seperti lewat telepon bahkan dapat saling melihat wajah (video call). Skype bahkan bisa memfasilitasi pembicaraan hingga 25 orang sekaligus dan merupakan pionir dalam teknologi video calling.

Jejaring sosial seperti Facebook tidak perlu dipertanyakan lagi kepopulerannya. Hampir setiap individu yang penulis temui, pasti memiliki akun facebook. Persis serupa dengan cara kerja facebook, aplikasi ketiga yang direkomendasikan pada seminar ini bernama LINKEDIN. Perbedaan situs jejaring sosial facebook dengan linkedIN hanyalah pada fokus linkedIN yang merupakan situs jejaring sosial profesional. LinkedIN memungkinkan setiap indidvidu untuk terkoneksi dengan tenaga kerja lainnya, tenaga professional dibidang yang digeluti bahkan dengan memiliki akun linkedIN, para individu dapat menerima informasi berupa banyak sekali lowongan pekerjaan

\section{Komunikasi Bisnis: Surat Lamaran, CV, Video Resume, Teknik Wawancara}

Modul penulisan surat lamaran dan daftar riwayat hidup ada pada lampiran tulisan ini, dimana dengan adanya aplikasi terbaru bernama canva,

Nama Sub tema Penelitian 
setiap pelamar kerja dapat dengan mudah mengolah template yang sudah disediakan oleh aplikasi tersebut. Aplikasi canva memudahkan setiap individu membuat baik itu surat lamaran, daftar riwayat hidup, kartu nama bahkan dengan disain yang menarik tanpa perlu mempelajari teknik disain. Efisiensi proses pembuatan surat lamaran ini dimungkinkan dengan adanya canva.

Dewasa ini, proses melamar suatu pekerjaan apalagi berbicara konteks MEA (lintas negara), maka ada suatu teknik komunikasi baru yaitu pembuatan video resume. Video resume, esensinya ialah sebuah daftar riwayat hidup yang diceritakan secara bertutur oleh si pelamar pekerjaan itu sendiri. Jadi, video resume dapat menggantikan posisi surat lamaran ataupun $\mathrm{CV}$ untuk dapat menarik hati pemberi pekerjaan. Keunggulan video resume pada dasarnya ialah seorang pelamar pekerjaan dapat menjelaskan atau mempromosikan dirinya sendiri dengan 2 bahasa sekaligus, misalnya ia berbicara dalam Bahasa Indonesia namun dapat diberikan subtitel dalam bahasa inggris yang memungkinkan pelamar melamar di wilayah ASEAN. Keunggulan lain ialah melalui video, calon pemberi pekerjaan dapat menilai kemampuan berkomunikasi seorang pelamar dari caranya mempromosikan dirinya sendiri melalui sebuah video berdurasi tidak lebih dari 2 menit.

Dan akhirnya, keterampilan berkomunikasi dalam dunia bisnis ialah dengan mempelajari kiatkiat untuk unggul dalam wawancara kerja. Pada seminar ini, penulis mengajarkan tentang beberapa tips yang dapat dikuasai oleh peserta seminar agar dapat unggul dalam wawancara pekerjaan. Bila dalam komunikasi digital, penulis menyarankan aplikasi skype untuk dapat melakukan proses wawancara jarak jauh (lintas negara), maka dalam bahasan komunikasi bisnis, ada beberapa tips yang perlu diingat oleh pelamar agar bias lolos dalam proses wanwancara kerja. Proses wawancara kerja tentu dibatasi oleh waktu, untuk itu setiap pelamar perlu memahami strategi unggul dalam wawancara kerja. Adapun kiat tersebut dapat dirangkum dalam akronim yang disebut sebagai format: STAR. Inti dari format STAR adalah dalam menjawab pertanyaan, pelamar harus menggunakan format STAR agar pesan dapat tersampaikan dengan singkat, padat dan jelas. Adapun kepanjangan dari STAR ialah SITUATION, TASK, ACTIONS dan RESULTS. S yang pertama, pelamar menjelaskan dalam situasi apa, $\mathbf{T}$ ialah tugas atau tantangan seperti apa yang diberikan sebelum ini atau pada organisasi sebelumnya, A ialah aksi; tindakantindakan apa saja yang dilakukan pelamar dalam menjawab tantangan tersebut lalu yang terakhir $\mathbf{R}$ ialah results; hasil seperti apa yang didapatkan pada akhirnya. Sehingga, dengan menggunakan format STAR diharapkan pewawancara mampu menilai apakah pelamar ini cocok untuk pekerjaan jenis ini karena jawaban yang diberikan sudah singkat, padat dan jelas seperti layaknya seorang professional (Martha Gage, 2019).

\section{Saran \& Kesimpulan}

Program kemitraan bersama Persekutuan GerejaGereja Indonesia di wilayah Banten dengan mengambil lokasi seminar di GPIB Jemaat Karunia, Ciputat, Tangerang Selatan sudah berlangsung pada tanggal 29 Juni 2019. Setiap peserta seminar sehari ini pulang membawa USB yang berisi seluruh materi pembinaan dari 3 pembicara terkait peran kita menghadapi MEA. Masyarakat Ekonomi ASEAN ialah regionalisasi sebagai respon atas globalisasi. Salah-satu faktor pendorong globalisasi ialah teknologi digital. Komunikasi digital menjadi suatu kebutuhan bagi masyarakat Indonesia tak terkecuali komunitas gereja. Teknologi digital merupakan pengembangan dari teknologi sebelumnya, yaitu analog. Itu sebabnya teknologi digital menjadi keniscayaan bagi setiap individu. Pembicara ketiga mengerucut pada peran individu dalam meningkatkan keterampilannya, terutama untuk menjawab tantangan MEA melalui kemampuan komunikasi digital dan komunikasi bisnis. Komunikasi digital dalam PkM ini menekankan pada penggunaan perangkat-perangkat digital maupun piranti lunak ataupun aplikasiaplikasi komputer (canva, skype, linkedIn), dan 
ditutup dengan kegiatan dosen dan mahasiswa ilmu komunikasi angkatan 2016 berbagi seputar keterampilan berkomunikasi yaitu tips menulis $\mathrm{CV}$, menghadapi wawancara kerja dan pembuatan video resume. Target peserta seminar ialah usia produktif dan di masa mendatang, kiranya PGIW Banten sebagai tuan rumah dapat mengahdirkan lebih banyak lagi peserta usia produktif agar lebih banyak lagi warga masyarakat yang siap menghadapi perubahan ekonomi global.

\section{Ucapan terima-kasih}

1. Lembaga Penelitian dan Pengabdian kepada Masyarakat, Universitas Pelita Harapan.

2. Fakultas Ilmu Sosial dan Ilmu Politik khususnya program studi Hubungan Internasional dan program studi Ilmu Komunikasi mahasiswa Angkatan 2016.

3. Persekutuan Gereja-Gereja di Indonesia Wilayah Banten.

4. Gereja Protestan di Indonesia bagian Barat, Jemaat Karunia, Ciputat, Tangerang.

\section{Daftar Pustaka}

Alsdorf, T. K. (2012). Every Good Endeavor. New York: Dutton, Penguin Group Inc.,USA.

Career News. (2019, september 01). careernews.id. Retrieved from https://careernews.id/youknow/view/3000 -8-Profesi-Ini-Bebas-Berkeliaran-di-ASEAN)
CERMATI. (2019, september 01). cermati.com. Retrieved from https://www.cermati.com/artikel/masyara kat-ekonomi-asean-mea-inilah-yang-perludiketahui

Detik. (2018, september 01). detik.com. Retrieved from finance.detik.com: https://finance.detik.com/berita-ekonomibisnis/d-3620255/60-angkatan-kerja-rilulusan-sd-dan-smp-ini-langkah-kemenaker

Kaczmarek, K. O. (2013). Business Communication: Building Critical Skills. New York: McGrawHill Irwin.

Lembaga Alkitab Indonesia . (1974). Alkitab. Bogor: LAI.

Martha Gage, E. C. (2019). The STAR Method Explained: Proven Technique to Succeed at Interview. Letterpeak.

Persekutuan Gereja-Gereja di Indonesia. (2019, september 01). PGIW Banten. Retrieved from pgi.or.id

Turow, J. (2014). Media Now: Mass Communication in Converging World. New York: Routledge.

UNDP. (2019, september 01). http://www.hdr.undp.org/en/countries/pro files/IDN. Retrieved from undp.org: http://www.hdr.undp.org/en/countries/pr ofiles/IDN 